\title{
Species effect on decay resistance of wood exposed to exterior conditions above the ground in Spain
}

\author{
๑M. Conde-García ${ }^{a},{ }^{\oplus}$ M Conde-García ${ }^{b}, \oplus J . I$. Fernández-Golfín ${ }^{a} \bowtie$ \\ a. Forest Products Department, Wood Technology Lab. CIFOR-INIA, (Madrid, Spain) \\ b. Universidad de Córdoba, Escuela Técnica Superior de Ingenieros Agrónomos y Montes, (Córdoba, Spain) \\ golfin@inia.es
}

\begin{abstract}
The objective of this study is to evaluate the effect of the species on the biological resistance of wood against decay and to propose corrective values of the critical dose. To evaluate the species effect, the evolution of the number of days per year with moisture content exceeding $18 \%$ was assessed in flat sawn 20x100x750 $\mathrm{mm}^{3}$ test samples of Laricio, Scots and Radiata pines and also of Norway spruce, Eucalypt (globulus) and sweet chestnut during the years 2016, 2017 and 2018, exposed at seven locations in Spain with the most representative Spanish climates. A value of 1.0 is proposed for the four conifers, 2.51 for the Eucalypt and 1.84 for the Sweet chestnut. As regards the species effect it was not possible to separate that corresponding to the different wetting/releasing ability of each species and that of their crack susceptibility, both aspects having to be evaluated together as "species factor".
\end{abstract}

KEY WORDS: Wood; Durability; Weathering; Permeability; Detection of cracks.

Citation/Citar como: Conde-García, M.; Conde-García, M.; Fernández-Golfín, J.I. (2021) Species effect on decay resistance of wood exposed to exterior conditions above the ground in Spain. Mater. Construcc. 71 [341], e236 https://doi.org/10.3989/ mc.2021.11320

RESUMEN: Efecto de la especie en la resistencia a la pudrición de la madera expuesta al exterior fuera del contacto con el suelo en España. El objetivo del estudio es evaluar el efecto de la especie en la resistencia de la madera frente a la pudrición y proponer valores de corrección de la dosis crítica. Para evaluar el factor especie, se analizó la evolución del número de días anuales con contenido de humedad superior al $18 \%$ en piezas de madera aserrada de 20x100x750 $\mathrm{mm}^{3}$ de los pinos Laricio, silvestre y radiata así como en Abeto rojo, Eucalipto (globulus) y castaño europeo durante los años 2016, 2017 y 2018, expuestas en siete localidades españolas elegidas por tener los climas más representativos. Se propone un valor de 1.0 para las cuatro coníferas, 2.51 para el eucalipto y 1.84 para el castaño. No fue posible diferenciar entre el efecto debido a la diferente capacidad de sorción/desorción de cada madera de aquél motivado por la diferente propensión al fendado, teniendo que ser integrados ambos aspectos en un único "factor especie".

PALABRAS CLAVE: Madera; Durabilidad; Envejecimiento; Permeabilidad; Detección de fisuras.

Copyright: (C2021 CSIC. This is an open-access article distributed under the terms of the Creative Commons Attribution 4.0 International (CC BY 4.0) License. 


\section{INTRODUCTION}

Predicting the performance of building products made from timber and other bio-based building materials has become increasingly important. Performance data are requested by designers, planners, authorities and approval bodies, but are rarely available (1).

Service life of timber structures in outdoor conditions is predominantly affected by the climatic conditions in terms of moisture and temperature over time (2). On-site wood decay is the result of a series of concomitant factors which make up the so-called "material climate" (the moisture content and temperature of the wood), which in turn has a direct impact on the service life of the wood products and constructions (3).

Different works at European level (4-6) have proposed new technical guidelines for the design of buildings constructed using timber with respect to durability and service life, based on a parametric system similar to that used in mechanical engineering. These guidelines are based on a limit state described as "onset of decay", defined as a state of fungal attack according to rating 1 in EN 252 (7), which corresponds to a slight attack which is described in the standard as the situation when perceptible surface changes are apparent, but very limited in their intensity and their position or distribution, with softening of the wood being the most common symptom.

As stated above, in analogy to mechanical engineering, the design principle used in these technical guides is based on the use of expression (Equation [1]) to evaluate every aspect of the design.

$$
\text { Exposure } \leq \text { Resistance [1] }
$$

In expression [A] the exposure is calculated taking into account the basic exposure doses at each site according to the daily averages for material climate, modified in accordance with all the factors influencing this material climate (local exposure conditions, sheltering, distance to ground, design of details and other concomitant factors). Similarly, the design-material resistance is calculated considering a critical dose against biological agents modified by all the factors that affect this basic resistance (wetting and drying ability and crack susceptibility of the species used, protection systems, stability, etc.).

This approach, considering a basic value, not only for exposure but also for resistance, modified by all the factors affecting the basic values, closely follows the factor method idea according to ISO 15686-1 (8) and is an engineering approach for evaluating each decision regarding design and species/protection.

According to Marteinsson (9), the first to propose the use of the factor method to evaluate wood durability, when applied to wood the "factor method" consists of determining a reference value for durability, hazard or "service life", which must then be corrected by applying a series of factors which take into account different concomitant aspects related to both the material itself (species, dimensions, treatments applied, type of material etc.) as well as the "climate" in which the material is employed, or other aspects such as design details or hazards associated with the failure of the element in question (10).

As regards the calculation of the design-material resistance to onset of decay (onwards $D_{R D}$ ) in expression [A], this value is defined by a critical dose $\left(D_{c r i t}\right)$ which is adjusted to account for specific properties of the material in terms of water uptake and release, protection against fungal attack, etc. ( $k$ factors in expression (Equation [2])) (6). As in the calculation of the characteristic value for exposure and given its common presence in the European building sector, Norway spruce (Picea abies) was chosen as reference material $(3,6)$.

$$
D_{R D}=D_{\text {crit }}{ }^{*} k_{w a}{ }^{*} k_{\text {inh }}{ }^{*} k_{\text {si }}
$$

Where:

$D_{\text {crit }}$ - is the critical dose corresponding to decay rating 1 according to EN 252 (7)

$k_{w a}$ - is a factor accounting for the effect of the physical properties of each wood species (e.g. wetting/releasing ability, crack susceptibility), relative to the reference species of Norway spruce

$k_{\text {inh }}$ - is a factor accounting for the inherent protective properties of the tested materials against decay, relative to the reference of untreated Norway spruce. If no relevant information is available, it is suggested that a value of $k_{\text {inh }}=1.0$ be applied for well-maintained coated wood (6).

$k_{s i}$ - are factors accounting for any other material properties that slow down wetting or limit remaining wet, always relative to the reference of untreated Norway spruce

In Isaksson et al. (11) $D_{\text {crit }}$ was evaluated for Scots pine sapwood and Douglas fir heartwood. It was found that the critical dose corresponding to decay rating 1 according to EN 252 (7) can be considered more or less independent of the material. Isaksson et al. (6) identified the observed differences between the performance of different species as being due to differences in water uptake/release (wetting ability) $\left(k_{w a}\right)$ and protective properties inherent in the material $\left(k_{i n h}\right)$.

As far as the wetting ability $\left(k_{w a}\right)$ is concerned, Brischke et al. (12) proposed the $k_{w a}$ values presented in the Table 1, expressed relative to the performance of untreated Norway spruce (Picea abies), which was chosen as the reference material and assigned a $k_{\text {wa }}$ value $=1.0$.

It should be noted that a viable set of test methods has not yet been commonly accepted and until this occurs, the abovementioned $k_{w a}$ values must be considered provisional. 
TABLE $1 . \boldsymbol{k}_{w a}$ values (12).

\begin{tabular}{ll}
\hline Wood species & $\boldsymbol{k}_{\text {wa }}$ \\
\hline Norway spruce (Picea abies) sapwood\&heartwood & 1.0 \\
Scots pine sapwood (Pinus sylvestris) & 0.8 \\
Scots pine heartwood (Pinus sylvestris) & 1.5 \\
European larch heartwood (Larix decidua) & 1.5 \\
Siberian larch heartwood (Larix sibirica) & 1.5 \\
Douglas fir heartwood (Pseudotsuga menziesii) & 1.5 \\
English oak heartwood (Quercus robur) & 1.0 \\
Black locust heartwood (Robinia pseudacacia) & 1.5 \\
Western Red Cedar, heartwood (Thuja plicata) & 1.5 \\
Coated materials & 2.0 \\
Preservative-treated wood, modified wood and wood & 1.0 \\
plastic composites (WPC) & \\
\hline
\end{tabular}

An aspect which should be highlighted given its importance in the performance of timber exposed to the highly variable climatic conditions typical throughout most of Spain, is the effect of cracks on the moisture content of the wood and therefore on its durability. Meyer-Veltrup et al. (13) studied the effect of artificial cracks on MC in Norway spruce but found a minor effect, although the duration of the exposition in the study was very limited (three months), so the results can only be considered preliminary.

Osawa et al. (14), working on flat grain redwood (Sequoia sempervirens) and Japanese cedar (Cryptomeria japonica) specimens used the X-ray densitometry method to study the effect of artificial cracks (slits) on moisture content distribution and found that high moisture content was only present at the bottom of the slits (at a depth of $20 \mathrm{~mm}$ ), this moisture content being over $30 \%$ after $8 \mathrm{~h}$ of drying, regardless of the species. These authors concluded that cracks reaching a depth of $20 \mathrm{~mm}$ from the surface might increase the risk of decay, at least in the species studied.

With regard to crack susceptibility, Meyer-Veltrup et al. (13) found high crack susceptibility in Scots pine and Norway spruce. They also concluded that cracks could provide a starting point for rot, which would affect service life, although they found no significant influence on MC.

Several previous studies have addressed the relationship between moisture content and fungal activity (studies cited in $(15,16)$, some of which have pointed to a risk of fungal attack even below the fibre saturation point, reaching the limit value of $16.3 \%$ in Picea abies (15). The risk of moisture leading to wood decay, however, is commonly considered to be above a moisture content of 20 to $30 \%$ (16-18). Morris and Winandy (19) considered moisture content of between $20 \%$ and $30 \%$ to be a suspicious grey area and therefore, for safety reasons, proposed a limit value of $20 \%$ to be used in North American light-framed construction.

Isaksson and Thelandersson (5), who considered a moisture content threshold level of $25 \%$ to be that at which the decay process becomes active, proposed a measure of the moisture trapping effect of different features (including cracks) counting for the number of days in a year in which the moisture content is above $25 \%$. This indicator (number of days with a given MC value) was also considered by Meyer-Veltrup and Brischke (3) as a useful and simple alternative indicator to the more complex and accurate performance models.

As regards the influence of temperature on fungal growth, Zak and Wildman (20) found that the majority of fungi appear to develop satisfactorily at temperatures of between 5 and $35^{\circ} \mathrm{C}$, while Viitanen (21) identified a lower limit for fungal development of $0^{\circ} \mathrm{C}$.

The objective of the present study is to improve our understanding of the factors affecting the biological resistance of timber and therefore the service life of timber elements by characterizing the effect of species under the prevalent climatic conditions in Spain.

The discernible effect of species on the expected service life of untreated timber is mainly due, apart from aspects related to the natural durability of each species, to certain physical characteristics, such as their susceptibility to cracking, degree of permeability or rate of release in drying, since all of these aspects affect the time of wetness (time during which the wood has a moisture content above the established risk threshold) at the surface in contact with the water and the depth reached by the moisture.

With respect to the effect of different wetting/releasing ability, wood species that are less permeable to water are expected to perform better than those which are more permeable in uses where wood is exposed to intermittent wetting (22). Hence, wetting/releasing ability is expected to play a crucial role in the performance of wood exposed to exterior conditions in those localities where rain events are short and scarce and dry periods are long and intense.

\section{MATERIALS AND METHODS}

In the context of the Spanish national project BIA2013-42434-R on the Evaluation of functional behaviour of wood in outdoor above ground applications, seven different field testing devices were deployed outdoors in seven different Spanish locations (Figure 1). These locations were chosen to include the effect of the most representative climates in Spain, reflected in their respective Scheffer index values (Table 2). 


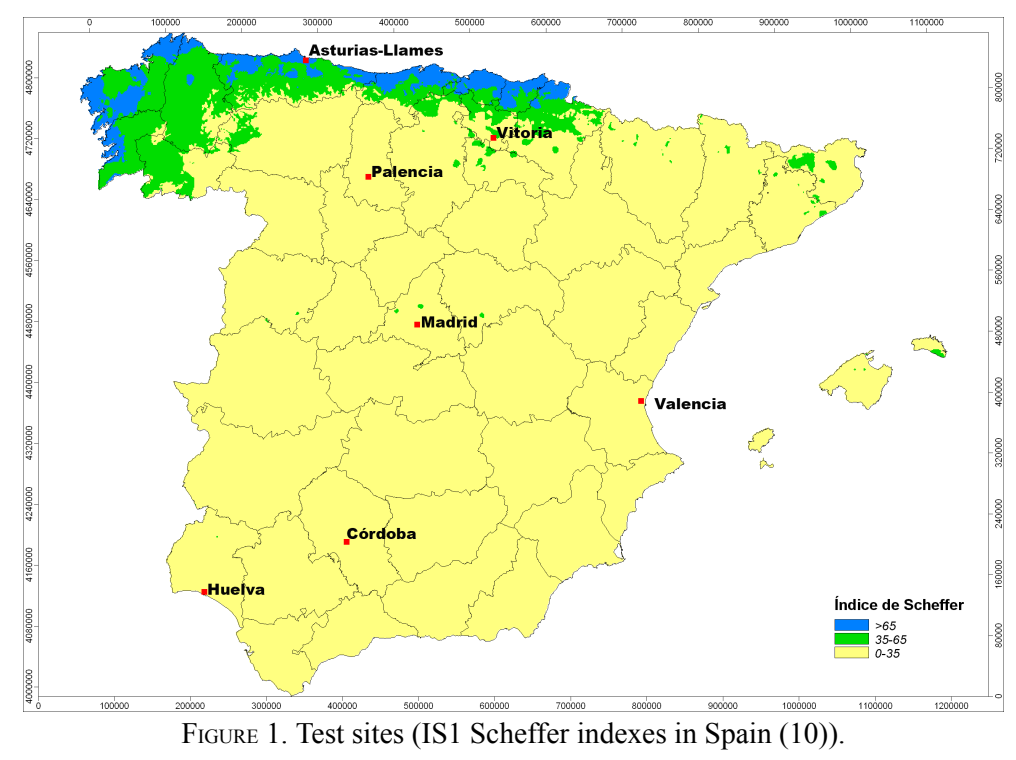

The Scheffer index (1971) is an index for estimating potential risk of decay in wood due to the effect of wood-degrading fungi. This index incorporates the multiplier effect of temperature $(\mathrm{T})$ above a specific threshold value $\left(2^{\circ} \mathrm{C}\right)$, a lower thermal limit for the growth of wood-rotting fungi, as well as precipitation frequency (the number of days per month, $\mathrm{D}$, with more than $0.25 \mathrm{~mm}$ precipitation in its initial formulation). The typical formulation in degrees Celsius is (Equation [3]):

$$
I S=\sum_{j a n}^{d e c} \frac{(T-2)(D-3)}{16.7}
$$

In this expression, a value of 16.7 is considered as the denominator of the equation so that the index value varied throughout the USA between 0 and 100 . This value can be redefined within each country or geographic zone so that the IS varies between 0 and 100. Fernández-Golfin et al. (10) made use of the original 16.7 value.

Table 2 shows the Sheffer index values for each locality, calculated according to AEMET climate data for the period 1981-2010, using two calculation methods proposed by Fernández-Golfin et al (10), without considering (IS1) and considering (IS2) the effect of condensation. The data in Table 2 reveal the discernible effects related to the presence of condensation and the reason why certain locations with similar IS1 values were chosen for the deployment of field testing devices.

Figure 1 provides a general view of the variability of the Scheffer index (IS1) values obtained in Spain (10) along with the location of each of the field testing devices.

Each field testing device comprised a metal frame (Figure 2) with seven planks of sawn wood mea-

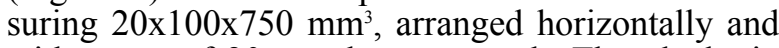
with a gap of $20 \mathrm{~mm}$ between each. The planks in each field-testing device were from three different pine wood types: Scots (PS), Laricio (PL) and Radiata (PR), as well as from Sweet chestnut (CS), Eucalyptus globulus (EU), thermo-treated radiata pine (at $210^{\circ} \mathrm{C}$ ) and Norway spruce (SP). These species were chosen because of their common presence in construction products in both the Spanish and European markets and because of their particular characteristics regarding wetting/releasing ability and crack susceptibility and the relationship of the latter with moisture and liquid water. The field testing devices were situated outdoors with no protection

TABLE 2. Sheffer indexes of each site.

\begin{tabular}{|c|c|c|c|c|c|}
\hline Locality & IS1 & IS2 & Climate & Collateral effects & Installation date \\
\hline Asturias-Llames (Private) & 81 & 126 & Northern-Atlantic coast & Sea effect & $19 / 03 / 2015$ \\
\hline Vitoria (NEIKER) & 45 & 76 & Continental & Large sources of humidity (lake) & $12 / 03 / 2015$ \\
\hline Palencia (University-ETSIAM) & 23 & 74 & Continental & Cold winters and dry summers & $28 / 01 / 2015$ \\
\hline Madrid (INIA) & 22 & 42 & Continental & Long, hot summer & $27 / 11 / 2014$ \\
\hline Cordoba (University-Rabanales) & 16 & 35 & Continental & Extremely hot summer & $07 / 04 / 2015$ \\
\hline Huelva (University-La Rábida) & 26 & 62 & Southern-Atlantic coast & Sea effect & $08 / 04 / 2015$ \\
\hline Valencia (Private) & 26 & 62 & Mediterranean coast & Sea effect & 4/03/2015 (removed 16/09/2015) \\
\hline
\end{tabular}




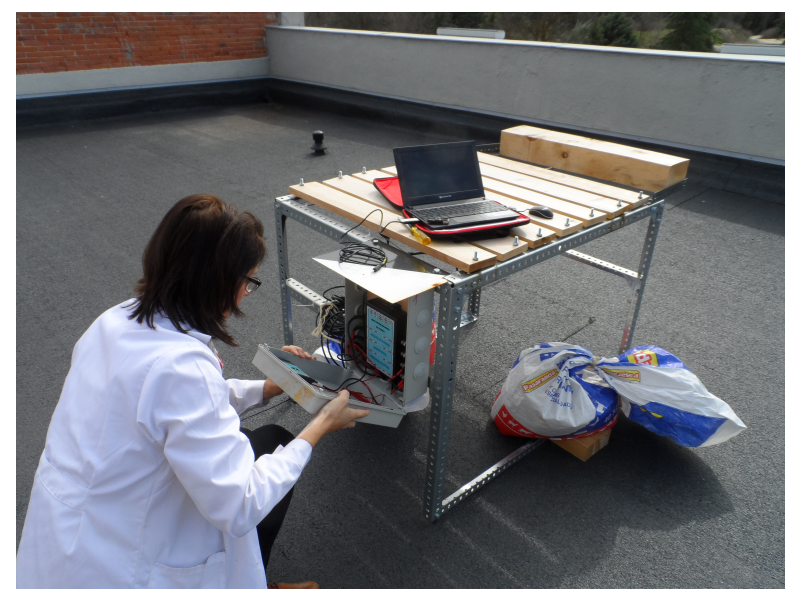

Figure 2. Trial set-up (Madrid).

at all against the sun or rainfall. All devices were arranged in a north-south direction (boards arranged in an east-west direction).

In each trial set-up, the moisture content of each of the seven solid wood pieces were recorded every two hours using a data logging device installed inside a protective box to prevent leaking (Figure 2). Moisture content measurements were made during 3 years $(2016,2017$ and 2018).

All the pieces included in each test device were selected from approximately tangentially sawn wood, placed with the pith facing upwards to avoid the collateral effect produced by excessive checking.

Stainless steel screws inserted from the lower face up to the centre of the pieces $(10 \mathrm{~mm})$ were used as moisture content sensors, the outer $7 \mathrm{~mm}$ of which were Teflon covered to avoid measuring the surface moisture. To determine the temperature of the wood a Resistance Temperature Detector (RTD) was inserted into one of the pieces (Scots pine) of wood in each trial and recorded at the same time than the moisture content.

The horizontal arrangement, separation and size of the planks in this approach as well as the measurement of the moisture content on the underside of the central part of the planks were adopted in accordance with the recommendations in Cost Action FP1303 (23) for the characterization of exterior wood performance at European level with the aim of creating a common database. The device used to measure and record the moisture content of the wood was composed of an eight channel moisture sensor (Type Gigamodule, Scanntronik $\mathrm{GmbH}$ ) and a datalogger (Type Thermofox, Scanntronik GmbH), which have commonly been employed in other similar studies conducted at European level, albeit under other climatic conditions. Maximum methodological coincidence was sought with other characterization studies at European level under Cost Action FP1303 in order to contribute to a European database and thus be able to compare results.
The seven testing devices were set up at the locations and dates listed in the Table 2.

The testing device located in Valencia was withdrawn in September 2016 due to a problem with permission for the installation. As the Valencia and Huelva locations have the same Scheffer index values (IS1 and IS2) as well as sea effect (Table 2) the Valencia device was not replaced by another and the location was removed from the analysis.

To obtain high quality data and avoid measurement errors, the functioning of the measurement device (Gigamodule) was continuously monitored by connecting a $10 \mathrm{Mohms}$ calibrated resistance to channel 8 as well as carrying out monthly controls using manual devices (GANN RTU600) for measuring the moisture content of every plank through moisture content sensors similar to those used for the primary measurements. These duplicated sensors were installed on the underside of each plank, at a distance of $50 \mathrm{~mm}$ from the primary sensors. Thus, a monthly comparison between primary and secondary measurements was performed, taking into account the acceptance criteria of maximum differences of $\pm 2 \%$. All the manual measurements were taken in the absence of active rain events. Fortunately, all the measurements were within the acceptance threshold.

In order to convert the electrical resistance readings (R) from the measurement devices to values for wood moisture content (MC), mathematical models were used to relate both variables to each other along with temperature. For the laricio, radiata and scots pines, as well as for the sweet chestnut, the thermo-treated radiata pine and the eucalyptus, the models used in this study were taken from previous studies (24-26). In the case of spruce, the model used was that published by Forsén and Tarvainen (27). Thus, the models finally used in the present study were the following (adjusted to $20^{\circ} \mathrm{C}$ ):

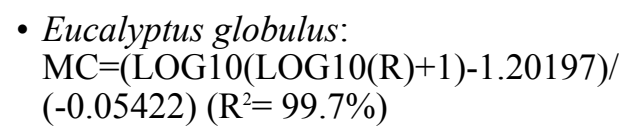

- Laricio Pine:

$\mathrm{MC}=(\mathrm{LOG} 10(\mathrm{LOG} 10(\mathrm{R})+1)-1.078018) /$ $(-0.03783)\left(\mathrm{R}^{2}=99.4 \%\right)$

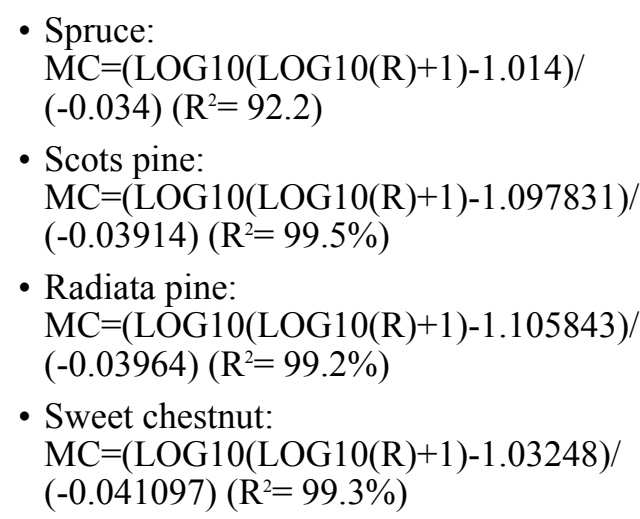


- Thermo-treated radiata pine:

$\mathrm{MC}=(\mathrm{LOG} 10(\mathrm{LOG} 10(\mathrm{R})+1)-1.08884) /$

$(-0.046215)\left(\mathrm{R}^{2}=99.7 \%\right)$

- Maritime pine:

$\mathrm{MC}=(\mathrm{LOG} 10(\mathrm{LOG} 10(\mathrm{R})+1)-1.093632)$

$(-0.04067)\left(\mathrm{R}^{2}=99.5 \%\right)$

The moisture content measurements were adjusted to $20^{\circ} \mathrm{C}$ according to our own and unpublished model, later included in the Scanntronik Softfox 3.03 software for automatic corrections.

To estimate species-specific decay potentials and how they are affected by the different climatological characteristics of sites, an index (NMC18) consisting of the number of days with moisture content greater than $18 \%$ was used in this study.

A critical limit of $18 \%$ in $\mathrm{MC}$ was used rather than a value within the interval $20 \%$ to $25 \%$ for the following reasons:

1. A MC value of $18 \%$ for solid timber represents the threshold of change from service class 2 to class 3 under norm EN 1995-1-1 (Eurocode 5) (28), also included in the Spanish Technical Building Code (29). This value of $18 \%$ is the limit based on which the engineer or design professional must calculate and consider requirements for products due to high moisture content. The use of this threshold allows conclusions to be drawn not only with regard to the biological durability, but also to the physical endurance of the timber elements, especially laminated and agglomerated timber products.

2. At all the locations in Spain, except for certain specific moments, the average temperature over the year (monthly average temperatures between $3^{\circ}$ and $30^{\circ} \mathrm{C}$ ) is favourable for the development of fungi, since it is well above the lower threshold of activity established by Viitanen (21). For this reason, it is necessary to consider a more conservative moisture content limit since a greater intensity of fungal attack can be expected.

3. As highlighted in the introduction, numerous studies have detected the colonization and even attack by fungi decay at moisture content levels below the fibre saturation point, and even at values below $18 \%$. Johannsson et al. (30) established a relative humidity (RH) of $80 \%$ at ambient temperature, corresponding to an EMC of $18 \%$ in solid wood, above which there is a non-negligible risk of fungi decay development. Similarly, Morris and Winandy (19) proposed a limit value of $20 \%$, for safety reasons, to be used in North American light-framed construction. These factors, combined with the favourable thermal conditions in the Iberian Peninsula for the rapid development of fungi decay, it was decided to adopt a conservative risk management strategy, using a MC threshold of $18 \%$.

4. The measurement technique used to estimate the moisture content of the wood (electrical resistance), when used in exterior conditions and on material with drying cracks (common in locations with high seasonal $\mathrm{MC}$ variation) presents notable uncertainty as the water accumulated in the cracks can lead to unusual high measurements. The intensity of cracking was high at all the locations except for Asturias-Llames, so unreal fluctuations occurred which affected the precision of the $\mathrm{MC}$ measurement. These abnormally high values last for short periods of time (4-8 hours) but are sufficient to artificially increase the number of days with $\mathrm{MC}$ values above 22 or $25 \%$ and affecting also the maximum $\mathrm{MC}$ values. In all the studied localities, a moisture content level above $18 \%$ already points to the presence of rain events and therefore the existence of a non-negligible risk of moisture content compatible with fungal attack.

Climate data for all sites were available from AEMET (Agencia Estatal de Meteorología, Spanish Metereological State Agency) weather stations, where measurements of daily precipitation, daily relative humidity $(\mathrm{RH})$ and average daily temperature were recorded.

All the wood samples from each of the field testing devices were evaluated every six months to detect the presence of decay according to EN 252 (7) (Table 3).

The moisture content of the thermo-treated radiata pine never exceeded the threshold of $18 \%$ at any time or location, hence it was excluded from the analysis.

The crack evaluation was carried out every six months during outdoor exposure, according to ISO 4628-4 criteria (31) (Table 4).

Regarding the analysis of crack susceptibility for the different wood species, our initial hypothesis was to consider that this susceptibility could be established by means of the use of the Coefficient of anisotropy (relation between tangential and radial shrinkage) and the Absolute anisotropy (difference between the total tangential and radial shrinkage). The values for both coefficients for the different wood species considered in the present study can be read in Table 5. These values were obtained according to ISO 4469 (32) methodology.

\section{RESULTS AND DISCUSSION}

Table 6 shows an annual summary of the main results per species and location. Table 7 presents a summary of the values recorded over the three years for each location and wood species. 
TABLE 3. Rating system for the assessment of attack caused by microorganisms on test samples.

\begin{tabular}{cll}
\hline Rating & Classification & Definition \\
\hline $\mathbf{0}$ & No attack & $\begin{array}{l}\text { No change perceptible by the means at the disposal of the inspector in the field. If only a change of color is } \\
\text { observed, It shall be rated } 0 .\end{array}$ \\
$\mathbf{1}$ & Slight attack & $\begin{array}{l}\text { Perceptible changes, but very limited in their intensity and their position or distribution: changes, which } \\
\text { only reveal themselves externally by superficial degradation, softening of the wood being the most common } \\
\text { symptom. }\end{array}$ \\
$\mathbf{2}$ & Moderate attack & $\begin{array}{l}\text { Clear changes: softening of the wood to a depth of at least } 2 \mathrm{~mm} \text { over a surface area covering at least } 10 \mathrm{~cm}^{2}, \\
\text { or softening to a depth of at least } 5 \mathrm{~mm} \text { over a surface area less than } 1 \mathrm{~cm}^{2} .\end{array}$ \\
$\mathbf{4}$ & Fevere attack & $\begin{array}{l}\text { Severe changes: marked decay in the wood to a depth of at least } 3 \mathrm{~mm} \text { over a wider surface (covering at least } \\
\left.25 \mathrm{~cm}^{2}\right), \text { or softening to a depth of at least } 10 \mathrm{~mm} \text { over a more limited surface area. } \\
\text { Impact failure of the sample in the field. }\end{array}$ \\
\hline
\end{tabular}

The data in tables 6 and 7 are derived from the daily data (measures taken at 12a.m.) for $\mathrm{MC}$ and temperature of the wood, from which monthly averages, an annual value (Table 6) and subsequently a value for the whole period, are calculated (Table 7).

The data shown in Table 6 are the following:

- "Rt": Total annual rainfall in mm

- "NR": Total number of rainfall days with precipitation of more than $0.2 \mathrm{~mm}$

- "NR10": Total number of rainfall days with precipitation of more than $10 \mathrm{~mm}$

- "NR50": Total number of rainfall days with precipitation of more than $50 \mathrm{~mm}$

- "NMC18": Total number of days with MC above $18 \%$

- "NMC18R": Percentage of the number of days with $\mathrm{MC}$ above $18 \%$ relative to the reference species (SP-Norway spruce), calculated for each location. For SP, NMC18R will always be 1.00

- "Aver NMC18R": Average value of NMC18R per species for the three years analyzed (2016, 2017, 2018)

- "SP": Wood species (EU-Eucalypt, PL-Laricio Pine, SP-Norway Spruce, PR-radiata Pine, CSChestnut)
Table 7 contains the following data:

- "IS1": Scheffer index calculated according to the original expression (10)

- "IS2": Scheffer index calculated taking into account the effect of condensations (10)

- " $\Sigma \mathrm{T}_{\text {med }}$ ": Summation (three years) of the average monthly temperatures

- " $\Sigma$ NT30": Summation (three years) of the number of days with temperature above $30^{\circ} \mathrm{C}$

- " $\Sigma \mathrm{NT}<10$ ": Summation (three years) of the number of days with temperature below $10^{\circ} \mathrm{C}$

- " $\Sigma \mathrm{Rt}$ ": Summation (three years) of the annual rainfall

- " $\Sigma$ NR": Summation (three years) of the number of days with rainfall of more than $0.2 \mathrm{~mm}$

- " $\Sigma$ NR10": Summation (three years) of the number of days with rainfall above $10 \mathrm{~mm}$

- " $\Sigma$ NR50": Summation (three years) of the number of days with rainfall above $50 \mathrm{~mm}$

- "NR50R": Percentage of days with rainfall above $50 \mathrm{~mm}$ ( $\Sigma \mathrm{NR} 50)$ with respect to the total $(\Sigma \mathrm{NR})$. This is a measure of the torrential nature of the rainfall.

TABLE 4. Classification of cracks according to ISO 4628-4.

\begin{tabular}{cll}
\hline Class & Number of cracks & Size of cracks \\
\hline $\mathbf{0}$ & No cracks visible & Not visible under x 10 magnification \\
$\mathbf{1}$ & Single cracks, barely visible and only on the surface & Visible under magnification up to x 10 \\
$\mathbf{2}$ & Small cracks, clearly visible on the surface & Visible with normal corrected vision \\
$\mathbf{3}$ & Moderate number of cracks & Clearly visible with normal corrected vision \\
$\mathbf{4}$ & Large number of cracks & Large cracks generally up to 1 mm wide \\
$\mathbf{5}$ & Very large number of cracks & Very large cracks generally more than 1 mm wide \\
\hline
\end{tabular}


TABLE 5. Physical properties of wood affecting wood-water relationships.

\begin{tabular}{lcccccccc}
\hline Property & Standard & Pine Scots & Pine Laricio & Pine Radiata & Spruce & Eucalypt & Chestnut & Source \\
\hline Coeff of anisotropy & ISO 4469 & 1.8 & 1.5 & 1.8 & $2.2^{*}$ & 2.3 & 2.2 & $(33)$ \\
Absolute anisotropy & ISO 4469 & 3.2 & 2.6 & 3.3 & 3.0 & 5.7 & 4.3 & $*(34)$ \\
\hline
\end{tabular}

If the Sheffer index average values (IS1) calculated using the climatic records taken at each site over the three years $(2016,2017$ and 2018) are compared with the historic data in Table 2 for the same sites, it can be observed that the climate over the considered three year period was drier than the historical series, which resulted in a notable reduction in the Sheffer index value and therefore in the risk of decay at all the locations. This fact alone explains the absence of decay in any of the wood samples at any of the locations, except for the Radiata pine at the Asturias-Llames site at the end of 2018, despite the presence of moderate to large levels of cracking at all the sites except Asturias-Llames.

Due to the generalized absence of decay at the different locations it is impossible to develop a predictive model addressing the relationship between the number of days with moisture content above $18 \%$ (NMC18) and the onset of decay according to wood species and location. Hence, this study only evaluates the relative risk of decay by considering the number of days with humidity content above (NMC18 in Table 6) as risk indicator and comparing the NMC18 values for each species with respect to the average values for Norway spruce (SP) at each location.

Norway spruce was chosen as the basis for comparison because this species is commonly used in studies evaluating $D_{\text {crit }}$, the critical dose for decay resistance $(3,6)$, and $k_{w a}$ indexes $(6,12)$.

With the exception of coastal areas (Asturias-Llames and to a lesser extent Huelva) or those affected by nearby sources of moisture (Vitoria, with big lakes closed to the device), the degree of cracking in all the wood samples can be classified as moderate to large, although with differences among species.

Focusing on the evaluation according to aspect, among the conifer species, especially at the sites with intense continental climates (Palencia, Madrid, Córdoba), the Scots pine is that which shows the highest level of cracking (level 4 in Table 4 ) at the end of the three year period, followed by Radiata pine (level 3) and Laricio pine (also level 3 but with less cracks than Radiata pine). Norway spruce presents an intermediate level of cracking (level 3 ), similar to that of Laricio pine. This conclusion agrees with the conclusion of Meyer-Veltrup et al. (13) regarding the high susceptibility of cracking of Scots Pine but does not confirm the initial hypothesis we had on the direct effect of the Coefficient of anisotropy and the Absolute anisotropy (Table 5) on the cracking behaviour. This difference in behaviour in the samples evaluated with respect to the expected theoretical behaviour suggests that in practice the susceptibility to cracking also depends on other factors such as the microstructure, chemical composition or permeability.

A notable difference can be observed in the performance of the hardwoods, being its cracking intensity much lower than that of the conifer species, despite having higher Coefficient of anisotropy and Absolute anisotropy values. Eucalyptus presents a large amount of short, shallow cracks (level 2), while the Sweet chestnut has very few cracks, although longer and deeper (level 1). This difference in the observed level of cracking between hardwoods and conifer species may be due to the notably stronger transversal microstructure and lower permeability of the hardwood species under study, which is evidenced by the lower NMC18 values at all the locations meaning that extreme variations in $\mathrm{MC}$ are much less frequent.

Since straight fibre pieces were selected in all cases, none of them presented twists.

As regards the relative values, with respect to Norway spruce, for the total number of days with a moisture content above $18 \%$ (NMC18R), as presented in the upper part of Table 7, the following aspects can be observed:

1. In the case of the softwoods (PS, PL, PR, SP):

a.In general, the values for the three pine species (PL, PS, PR) reflect similar performance, since the relative index values are close to one, with the exception of PR in Cordoba.

b.As expected, the most permeable woods; Laricio pine (PL) and especially Radiata pine (PR), seem to present lower NMC18R values in those locations where the sum of the monthly average temperatures is warmer (higher $\Sigma \mathrm{T}_{\text {med }}$ values) and where there are more high-temperature events, represented by higher $\Sigma$ NT30 values (Madrid, Cordoba and Huelva). In these locations, the torrential risk index represented by the NR50R value is also higher. This effect can be explained by the short duration of the rain events (2 days on average) and long duration of the dry periods also with the greater drying ability of PL and PR drives to reduced values of $\mathrm{MC}$ for more days during the year (see NMC18 values for these species per year in Table 6). At the Huelva site these values are less appreciable than in Cordoba and Madrid due to the sea proximity effect in Huelva, which leads to higher annual average relative humidity and therefore slower drying rate and smaller number of cracks (due to lower annual variations in $\mathrm{MC}$ values). 
TABLE 6. Summary of annual results per species and location.

\begin{tabular}{|c|c|c|c|c|c|c|c|c|c|c|c|c|c|c|c|c|c|c|c|}
\hline Place & SP & Year & $\mathbf{R t}$ & NR & NR10 & NR50 & NMC18 & NMC18R & Aver_NMC18R & Place & SP & Year & Rt & NR & NR10 & NR50 & NMC18 & NMC18R & Aver_NMC18R \\
\hline Llames & EU & 2016 & 979.5 & 156 & 105 & 67 & 21 & 0.06 & & Huelva & EU & 2016 & 559.2 & 61 & 52 & 32 & 18 & 0.26 & \\
\hline Llames & $\mathrm{EU}$ & 2017 & 1239.6 & 174 & 131 & 74 & 20 & 0.05 & 0.07 & Huelva & $\mathrm{EU}$ & 2017 & 513.7 & 33 & 30 & 17 & 13 & 0.25 & 0.27 \\
\hline Llames & $\mathrm{EU}$ & 2018 & 1281.3 & 182 & 134 & 76 & 30 & 0.08 & & Huelva & $\mathrm{EU}$ & 2018 & 588.0 & 85 & 61 & 33 & 28 & 0.29 & \\
\hline Llames & $\mathrm{PL}$ & 2016 & & & & & 313 & 0.95 & & Huelva & PL & 2016 & & & & & 60 & 0.88 & \\
\hline Llames & PL & 2017 & & & & & 349 & 0.96 & 0.96 & Huelva & PL & 2017 & & & & & 50 & 0.94 & 0.91 \\
\hline Llames & PL & 2018 & & & & & 356 & 0.98 & & Huelva & PL & 2018 & & & & & 88 & 0.90 & \\
\hline Llames & SP & 2016 & & & & & 330 & 1.00 & & Huelva & SP & 2016 & & & & & 68 & 1.00 & \\
\hline Llames & SP & 2017 & & & & & 365 & 1.00 & 1.00 & Huelva & SP & 2017 & & & & & 52 & 1.00 & 1.00 \\
\hline Llames & SP & 2018 & & & & & 365 & 1.00 & & Huelva & SP & 2018 & & & & & 98 & 1.00 & \\
\hline Llames & PS & 2016 & & & & & 324 & 0.98 & & Huelva & PS & 2016 & & & & & 70 & 1.03 & \\
\hline Llames & PS & 2017 & & & & & 363 & 0.99 & 0.99 & Huelva & PS & 2017 & & & & & 57 & 1.08 & 1.04 \\
\hline Llames & PS & 2018 & & & & & 360 & 0.99 & & Huelva & PS & 2018 & & & & & 99 & 1.01 & \\
\hline Llames & PR & 2016 & & & & & 319 & 0.97 & & Huelva & PR & 2016 & & & & & 59 & 0.87 & \\
\hline Llames & PR & 2017 & & & & & 363 & 1.00 & 0.98 & Huelva & PR & 2017 & & & & & 46 & 0.87 & 0.87 \\
\hline Llames & PR & 2018 & & & & & 358 & 0.98 & & Huelva & PR & 2018 & & & & & 86 & 0.88 & \\
\hline Llames & $\mathrm{CS}$ & 2016 & & & & & 169 & 0.51 & & Huelva & CS & 2016 & & & & & 32 & 0.47 & \\
\hline Llames & CS & 2017 & & & & & 201 & 0.55 & 0.54 & Huelva & $\mathrm{CS}$ & 2017 & & & & & 22 & 0.42 & 0.44 \\
\hline Llames & $\mathrm{CS}$ & 2018 & & & & & 208 & 0.57 & & Huelva & $\mathrm{CS}$ & 2018 & & & & & 43 & 0.44 & \\
\hline Place & SP & Year & $\mathbf{R t}$ & NR & NR10 & NR50 & NMC18 & NMC18R & Aver_NMC18R & Place & SP & Year & $\mathbf{R t}$ & NR & NR10 & NR50 & NMC18 & NMC18R & Aver_NMC18R \\
\hline Vitoria & $\mathrm{EU}$ & 2016 & 683.1 & 162 & 110 & 39 & 33 & 0.18 & & Cordoba & $\mathrm{EU}$ & 2016 & 597.4 & 73 & 61 & 37 & 24 & 0.35 & \\
\hline Vitoria & $\mathrm{EU}$ & 2017 & 613.9 & 130 & 90 & 40 & 35 & 0.19 & 0.19 & Cordoba & $\mathrm{EU}$ & 2017 & 339.3 & 48 & 40 & 22 & 15 & 0.39 & 0.40 \\
\hline Vitoria & EU & 2018 & 693.6 & 167 & 120 & 50 & 49 & 0.21 & & Cordoba & $\mathrm{EU}$ & 2018 & 619.7 & 92 & 67 & 36 & 38 & 0.45 & \\
\hline Vitoria & $\mathrm{PL}$ & 2016 & & & & & 185 & 0.98 & & Cordoba & PL & 2016 & & & & & 61 & 0.88 & \\
\hline Vitoria & PL & 2017 & & & & & 180 & 0.96 & 0.98 & Cordoba & PL & 2017 & & & & & 33 & 0.87 & 0.91 \\
\hline Vitoria & PL & 2018 & & & & & 230 & 0.98 & & Cordoba & PL & 2018 & & & & & 83 & 0.99 & \\
\hline Vitoria & SP & 2016 & & & & & 188 & 1.00 & & Cordoba & SP & 2016 & & & & & 69 & 1.00 & \\
\hline Vitoria & SP & 2017 & & & & & 187 & 0.80 & 1.00 & Cordoba & SP & 2017 & & & & & 38 & 1.00 & 1.00 \\
\hline Vitoria & SP & 2018 & & & & & 235 & 1.00 & & Cordoba & SP & 2018 & & & & & 84 & 1.00 & \\
\hline
\end{tabular}


TABLE 6. Cont.

\begin{tabular}{|c|c|c|c|c|c|c|c|c|c|c|c|c|c|c|c|c|c|c|c|}
\hline Place & SP & Year & Rt & NR & NR10 & NR50 & NMC18 & NMC18R & Aver_NMC18R & Place & SP & Year & Rt & NR & NR10 & NR50 & NMC18 & NMC18R & Aver_NMC18R \\
\hline Vitoria & PS & 2016 & & & & & 191 & 1.02 & & Cordoba & PS & 2016 & & & & & 74 & 1.07 & \\
\hline Vitoria & PS & 2017 & & & & & 191 & 1.02 & 1.02 & Cordoba & PS & 2017 & & & & & 42 & 1.11 & 1.09 \\
\hline Vitoria & PS & 2018 & & & & & 243 & 1.03 & & Cordoba & PS & 2018 & & & & & 91 & 1.08 & \\
\hline Vitoria & $\mathrm{PR}$ & 2016 & & & & & 186 & 0.99 & & Cordoba & PR & 2016 & 597.4 & 73 & 61 & 37 & 52 & 0.75 & \\
\hline Vitoria & PR & 2017 & & & & & 181 & 0.97 & 0.99 & Cordoba & PR & 2017 & 339.3 & 48 & 40 & 22 & 32 & 0.84 & 0.81 \\
\hline Vitoria & PR & 2018 & & & & & 239 & 1.02 & & Cordoba & PR & 2018 & 619.7 & 92 & 67 & 36 & 70 & 0.83 & \\
\hline Vitoria & $\mathrm{CS}$ & 2016 & & & & & 100 & 0.53 & & Cordoba & $\mathrm{CS}$ & 2016 & 597.4 & 73 & 61 & 37 & 22 & 0.32 & \\
\hline Vitoria & CS & 2017 & & & & & 95 & 0.51 & 0.51 & Cordoba & $\mathrm{CS}$ & 2017 & 339.3 & 48 & 40 & 22 & 11 & 0.29 & 0.32 \\
\hline Vitoria & $\mathrm{CS}$ & 2018 & & & & & 115 & 0.49 & & Cordoba & $\mathrm{CS}$ & 2018 & 619.7 & 92 & 67 & 36 & 30 & 0.36 & \\
\hline Place & SP & Year & Rt & NR & NR10 & NR50 & NMC18 & NMC18R & Aver_NMC18R & Place & SP & Year & $\mathbf{R t}$ & NR & NR10 & NR50 & NMC18 & NMC18R & Aver_NMC18R \\
\hline Palencia & $\mathrm{EU}$ & 2016 & 353.8 & 95 & 63 & 22 & 47 & 0.27 & & Madrid & $\mathrm{EU}$ & 2016 & 453.5 & 92 & 67 & 34 & 45 & 0.36 & \\
\hline Palencia & EU & 2017 & 187.7 & 60 & 40 & 14 & 25 & 0.30 & 0.29 & Madrid & $\mathrm{EU}$ & 2017 & 283.8 & 58 & 36 & 14 & 10 & 0.37 & 0.37 \\
\hline Palencia & EU & 2018 & 531.4 & 120 & 89 & 36 & 58 & 0.30 & & Madrid & $\mathrm{EU}$ & 2018 & 522.3 & 103 & 75 & 32 & 41 & 0.39 & \\
\hline Palencia & $\mathrm{PL}$ & 2016 & & & & & 149 & 0.87 & & Madrid & $\mathrm{PL}$ & 2016 & & & & & 115 & 0.91 & \\
\hline Palencia & $\mathrm{PL}$ & 2017 & & & & & 70 & 0.83 & 0.85 & Madrid & PL & 2017 & & & & & 25 & 0.93 & 0.91 \\
\hline Palencia & $\mathrm{PL}$ & 2018 & & & & & 168 & 0.86 & & Madrid & $\mathrm{PL}$ & 2018 & & & & & 96 & 0.91 & \\
\hline Palencia & SP & 2016 & & & & & 172 & 1.00 & & Madrid & SP & 2016 & & & & & 126 & 1.00 & \\
\hline Palencia & SP & 2017 & & & & & 84 & 1.00 & 1.00 & Madrid & SP & 2017 & & & & & 27 & 1.00 & 1.00 \\
\hline Palencia & SP & 2018 & & & & & 196 & 1.00 & & Madrid & SP & 2018 & & & & & 106 & 1.00 & \\
\hline Palencia & PS & 2016 & & & & & 166 & 0.97 & & Madrid & PS & 2016 & & & & & 135 & 1.07 & \\
\hline Palencia & PS & 2017 & & & & & 78 & 0.93 & 0.95 & Madrid & PS & 2017 & & & & & 29 & 1.07 & 1.07 \\
\hline Palencia & PS & 2018 & & & & & 190 & 0.97 & & Madrid & PS & 2018 & & & & & 113 & 1.07 & \\
\hline Palencia & PR & 2016 & & & & & 146 & 0.85 & & Madrid & PR & 2016 & & & & & 110 & 0.87 & \\
\hline Palencia & PR & 2017 & & & & & 66 & 0.79 & 0.82 & Madrid & PR & 2017 & & & & & 24 & 0.89 & 0.89 \\
\hline Palencia & PR & 2018 & & & & & 162 & 0.83 & & Madrid & PR & 2018 & & & & & 95 & 0.90 & \\
\hline Palencia & CS & 2016 & & & & & 55 & 0.32 & & Madrid & $\mathrm{CS}$ & 2016 & & & & & 42 & 0.33 & \\
\hline Palencia & CS & 2017 & & & & & 25 & 0.30 & 0.32 & Madrid & CS & 2017 & & & & & 10 & 0.37 & 0.37 \\
\hline Palencia & CS & 2018 & & & & & 70 & 0.36 & & Madrid & CS & 2018 & & & & & 42 & 0.40 & \\
\hline
\end{tabular}

Materiales de Construcción 71 (341), January-March 2021, e236. ISSN-L: 0465-2746. https://doi.org/10.3989/mc.2021.11320 
TABLE 7. Summary of the three years of climatic records measured for each location and species.

\begin{tabular}{|c|c|c|c|c|c|c|}
\hline \multirow{2}{*}{ Species } & \multicolumn{6}{|c|}{ LOCATIONS (average NMC18R) } \\
\hline & Llames & Vitoria & Palencia & Madrid & Cordoba & Huelva \\
\hline PL & 0.96 & 0.98 & 0.85 & 0.91 & 0.91 & 0.91 \\
\hline $\mathbf{P R}$ & 0.98 & 0.99 & 0.82 & 0.89 & 0.81 & 0.87 \\
\hline PS & 1.02 & 1.02 & 0.95 & 1.07 & 1.09 & 1.04 \\
\hline SP & 1.00 & 1.00 & 1.00 & 1.00 & 1.00 & 1.00 \\
\hline $\mathbf{E U}$ & 0.07 & 0.19 & 0.29 & 0.37 & 0.40 & 0.27 \\
\hline CS & 0.54 & 0.51 & 0.32 & 0.37 & 0.32 & 0.44 \\
\hline Species & \multicolumn{6}{|c|}{ 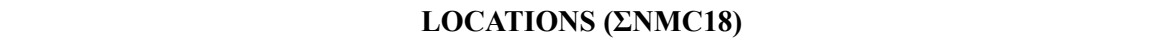 } \\
\hline SP & 1060 & 610 & 452 & 259 & 191 & 218 \\
\hline \multicolumn{7}{|c|}{ Clima (3 years) } \\
\hline IS1 & 42 & 24 & 10 & 10 & 14 & 14 \\
\hline $\boldsymbol{\Sigma} \mathbf{T}_{\text {med }}$ & 528,2 & 437,9 & 424,2 & 547,9 & 649,3 & 517.6 \\
\hline ENT30 & 0 & 1 & 1 & 17 & 81 & 13 \\
\hline$\Sigma \mathrm{NT}<10$ & 148 & 451 & 507 & 392 & 174 & 57 \\
\hline$\Sigma \mathbf{R t}$ & 3500.4 & 1990.6 & 1072.9 & 1259.6 & 1557.9 & 1661.0 \\
\hline$\Sigma N R$ & 512 & 459 & 275 & 253 & 213 & 179 \\
\hline$\Sigma$ NR10 & 370 & 320 & 192 & 178 & 168 & 143 \\
\hline 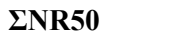 & 217 & 129 & 72 & 80 & 95 & 82 \\
\hline$\Sigma$ NR70 & 174 & 84 & 53 & 59 & 71 & 71 \\
\hline NR50R (\%) & 42 & 28 & 26 & 32 & 45 & 46 \\
\hline
\end{tabular}

2. In the case of the hardwoods (EU and CS):

a.The reduced wetting ability of eucalyptus leads to lower NMC18 values at all sites, this effect being much more evident at the sites with highest rainfall (Asturias-Llames and Vitoria). The more rapid drying of chestnut in comparison to eucalyptus leads to lower NMC18 values in chestnut at those sites with fewer rain events (Palencia, Madrid, Cordoba and Huelva).

b.The slower drying rate of eucalyptus also results in less cracking compared to chestnut, not only due to smaller differences between maximum and minimum $\mathrm{MC}$ but also to lower drying stress values.

It is not possible to determine the effect of cracking in wood exposed to outdoor conditions only by analysing the absolute and relative NMC18 values obtained (Tables 6 and 7) at the different sites, nor is it possible to confirm the affirmation of Meyer-Veltrup et al. (13) with respect to the limited influence of cracking in the MC of exterior wood. Therefore, the different performance observed among species can only be attributed to the joint contribution of their different wetting/releasing ability along with their susceptibility to cracking.
Hence, the NM18R values presented in Tables 6 and 7 can be used to obtain the species factor $\left(k_{w a}\right)$ value for the studied species.

The $k_{w a}$ values proposed in this study for the considered species will be the inverse of the maximum NMC18R values for each species, taking into consideration the six sites analyzed as a whole. These proposed values are shown in Table 8 .

TABLE $8 . k_{w a}$ values.

\begin{tabular}{lc}
\hline Species & $\boldsymbol{k}_{\text {wa }}$ \\
\hline PL & 1,03 \\
PR & 1,01 \\
PS & 0,92 \\
SP & 1,00 \\
EU & 2,51 \\
CS & 1,84 \\
\hline
\end{tabular}

In accordance with the data in Table 7 it would appear logical to use, for simplicity, a common value of 1.0 for all the conifers analyzed, 2.51 for the eucalyptus and 1.84 for the chestnut. 


\section{CONCLUSIONS}

The wood species factor can have a decisive influence on the decay resistance of wood exposed to outdoor condition because it affects the number of days per year in which the wood has high moisture content values. This is confirmed by the data obtained for the hardwood species, eucalyptus and chestnut, considered in this study. However, it has not been confirmed in the case of wood from the conifer species studied, since their performance can be described as being very similar from one to the other as well as to the reference species of Norway spruce.

The observed difference in the performance of the wood from the different conifer species at the studied locations may be due to their differing wetting/releasing ability and to a lesser degree to their susceptibility to cracking. The intensity of the effect of each of these variables could not be verified since the effects of each are intertwined, although the data obtained seems to point to a limited effect of cracks, mainly associated with the generation of short, intense and non-real increases in the average moisture content. All of the locations, with the exception of those with the wettest climates (Asturias-Llames, Vitoria and to a lesser extent, Huelva) show very similar crack presence levels, so the differences in performance of the wood from the different species at these locations can only be due to the differences in wetting/releasing ability.

Based on the above information, it can be deduced that the "physical" effect of the species factor on the resistance to fungi decay must be taken into account as a whole, which, according to $(3,6,11)$ is the so-called species factor.

Based on the results, it is proposed that a value of 1.0 be employed as "species factor" for the four studied conifers, 2.51 for the Eucalyptus and 1.84 for the Sweet chestnut.

\section{ACKNOWLEDGEMENTS}

This work was carried out in the Wood Technology Laboratories at the CIFOR-INIA and University of Cordoba, and was financially supported under the Spanish National RDT Plan through Grant BIA2013-42434-R and the Operational Group "Wood Sustainable Construction" of the European Association for Innovation in Agricultural Productivity and Sustainability (AEI-AGRI). The authors would like to thank all those who have collaborated in the trials, especially NEIKER in the Basque country, Rafael Sanchez at the University of Cordoba, Eugenio Perea at the Asturias-Llames site and Rafael Capuz at the Valencia sites.

\section{REFERENCES}

1. Brischke, C.; Jones, D. (2016) Performance of bio-based building products - Recent activities within COST Action FP 1303; Holztechnologie. 57 [2], 47-54.

2. Brischke, C.; Rapp, A.O.; Bayerbach, R. (2007) Decay influencing factors: a basis for service life prediction of wood and wood-based products. Wood. Mat. Sci. Eng. 1 [3-4], 91-107. https://doi.org/10.1080/174802706010 19658.

3. Meyer-Veltrup, L.; Brischke, C. (2017) Design and performance prediction of timber structures based on a factorization approach. IRG/WP 17-20603. IRG; Stockholm.

4. Thelandersson, S.; Isaksson, T.; Frühwald, E.; Toratti, T.; Viitanen, H.; Grüll, G.; Jermer, J.; Suttie, E. (2011) WoodExter-Service life and performance of exterior wood above ground. Report TVBK-3060. ISBN 978-91-979543$0-3$. Lund University; Sweden.

5. Isaksson, T.; Thelandersson, S. (2013) Experimental investigation on the effect of detail design on wood moisture content in outdoor above ground applications. Build. Environ. 59, 239-249. https://doi.org/10.1016/ j.buildenv.2012.08.023.

6. Isaksson, T.; Thelandersson, S.; Jermer, J.; Brischke, C. (2015) Service life of wood in outdoor above ground applications: Engineering design guideline. Background document Rapport TVBK-3067. Lund University; Division of Structural Engineering; Lund; Sweden. ISBN 978-87993-02-2.

7. EN 252:2015 Field test method for determining the relative protective effectiveness of a wood preservative in ground contact. European Committee for Standardization.

8. ISO 15686-1 (2011) Buildings and constructed assets Service life planning - Part 1: General principles and framework. International Organization for Standardization; Genève.

9. Marteinsson, B. (2003) Durability and the factor method of ISO 15686-1. Build. Res. Inf. 31 [6], 416-426. https:// doi.org/10.1080/0961321032000105412.

10. Fernandez-Golfin, J.I.; Larrumbide, E.; Ruano, A.; Galvan, J.; Conde, M. (2016). Wood decay hazard in Spain using the Scheffer index: proposal for an improvement. Eur. J. Wood Prod. 74, 591-599. https://doi.org/10.1007/ s00107-016-1036-z.

11. Isaksson, T.; Brischke, C.; Thelandersson, S. (2013) Development of decay performance models for outdoor timber structures. Mater. Struct. 46, 1209-1225. https:// doi.org/10.1617/s11527-012-9965-4.

12. Brischke, C.; Hesse, C.; Meyer, L.; Bardage, S.; Jermer, J.; Isaksson, T. (2014). Moisture dynamics of wood- An approach to implement the wetting ability of wood into a resistance classification concept. Proceedings IRG annual meeting 2014. IRG/WP 14-20557. IRG; Stockholm.

13. Meyer-Veltrup, L.; Brischke, C.; Goritzka, C.; Hundhausen, U. (2016). Formation of cracks in wooden elements design; moisture and durability aspects. COST FP 1303 4th Conference 'Designing with bio-based building materials challenges and opportunities' 24-25 February 2016; Madrid; Spain.

14. Osawa, T.; Maeda, K.; Tsunetsugu, Y.; Shida, S. (2019). Influence of surface checks on wood moisture content during wetting and re-drying. Eur. J. Wood Prod. 77 681-689. https://doi.org/10.1007/s00107-019-01423-w.

15. Brischke, C.; Soetbeer, A.; Meyer-Veltrup, L. (2017). The minimum moisture threshold for wood decay by basidiomycetes revisited. A review and modified pile experiments with Norway spruce and European beech decayed by Coniophora puteana and Trametes versicolor. Holzforschung. 71 [11], 893-903. https://doi.org/10.1515/ hf-2017-0051.

16. Rapp, A.O.; Peek, R.D.; Sailer, M. (2000). Modelling the moisture induced risk of decay for treated and untreated 
wood above ground. Holzforschung. 54 [2], 111-118. https://doi.org/10.1515/HF.2000.019.

17. Råberg, U.; Edlund, M.L.; Terziev, N.; Land, C.J. (2005) Testing and evaluation of natural durability of wood in above ground conditions in European overview. J. Wood Sci. 51, 429-440. https://doi.org/10.1007/s10086-0050717-8.

18. Meyer, L.; Brischke, C. (2015). Fungal decay at different moisture levels of selected European-grown wood species. Int. Biodeter. Biodegr. 103, 23-29. https://doi.org/10.1016/ j.ibiod.2015.04.009.

19. Morris, P.; Winandy, J.E. (2002). Limiting Conditions for Decay in Wood Systems. International Research Group on Wood Protection; Stockholm; IRG/WP 02-10421. IRG; Stockholm

20. Zak, J.C.; Wildman, H.G. (2004). 14 - Fungi in stressful environments. In Biodiversity of fungi. Burlington: Academic Press; 303-315. https://doi.org/10.1016/ B978-012509551-8/50017-9.

21. Viitanen, H.A. (1997) Modelling the time factor in the development of brown rot decay in Pine and Spruce sapwood-the effect of critical humidity and temperature conditions. Holzforschung. 51, 99-106. https://doi.org/ 10.1515/hfsg.1997.51.2.99.

22. Kutnik, M.; Suttie, E.; Brischke, C. (2014) European standards on durability and performance of wood and wood-based products - Trends and challenges. Wood Mater. Sci. Eng. 9 [3], 122-133. https://doi.org/10.1080/17480272. 2014.894574.

23. Brischke, C.; Humar, M.; Meyer, L.; Bardage, S.; Van den Bulcke, J. (2014). Cost Action FP 1303. Cooperative Performance Test. Instructions for participants.

24. Fernandez-Golfin, J.I.; Conde, M.; Conde, M.; FernandezGolfin, J.J.; Calvo, R.; Baonza, M.V.; de Palacios, P. (2012). Curves for the estimation of the moisture content of ten hardwoods by means of electrical resistance measurements. Forest Syst. 21 [1], 121-127. https://doi.org/ $10.5424 /$ fs $/ 2112211-11429$.
25. Fernández-Golfín, J.I.; Conde García, M.; FernándezGolfín, J.J.; Conde García, M.; Hermoso, E.; Cabrero, J.C. (2014). Effect of temperature of thermotreatment on electrical conductivity of radiata pine timber. Maderas. Cienc. Tecnol. 16 [1], 25-36. https://doi.org/10.4067/ S0718-221X2014005000003.

26. Conde García, M.; Conde García, M.; Fernández-Golfín, J.I. (2020). Improving the performance of wood moisture content measuring devices by new calibration curves for four European softwoods growing in Spain. Wood mater Sci. Eng. (In edition).

27. Forsén, H.; Tarvainen, V. (2000). Accuracy and functionality of hand held wood moisture content meters. VTT publications num. 420.95 pp. ISBN 951-38-5581-3.

28. EN 1995-1-1:2016 Eurocode 5: Design of timber structures - Part 1-1: General - Common rules and rules for buildings.

29. Ministerio de Fomento (2009). Documento Básico SE-M Seguridad Estructural Madera. Código Técnico de la Edificación (in Spanish).

30. Johansson, P.; Bok, G.; Ekstrand-Tobin, A. (2013). The effect of cyclic moisture and temperature on mould growth on wood compared to steady state conditions. Build. Environ. 65, 178-184. https://doi.org/10.1016/j.buildenv. 2013.04.004

31. ISO 4628-4 (2004): Paints and varnishes - Evaluation of degradation of coatings - Designation of quantity and size of defects; and of intensity of uniform changes in appearance - Part 4: Assessment of degree of cracking

32. ISO 4469:1981 Wood - Determination of radial and tangential shrinkage. International Organization for Standardization.

33. Fernández-Golfín Seco, J.I.; Conde García, M. (2007) Manual técnico de secado de maderas. 2019 p. ISBN 978-84-87381-37-9. Asociación de Investigación Técnica de las Industrias de la Madera y el Corcho (https:// infomadera.net/modulos/publicaciones.php? $\mathrm{id}=6 \&$ claseact $=$ publicaciones .

34. Bengtsson, C. (2001). Variation of moisture induced movements in Norway spruce (Picea abies). Ann. For. Sci. $58,569-581$. 